\title{
Discover the Prairie Coteau
}

\section{Located in the heartland of America, this unique region showcases the diverse tallgrass prairie.}

By Alexander Smart, Pete Bauman, and Barry Dunn

The prairie region landscape of the United State's upper Midwest has been described as a combination of low rolling hills with vast flat expanses. There is very little in the way of distinctive land features except for the coulees that rise above the major rivers that drain this vast landscape stretching from Minnesota and Iowa across the eastern part of the Dakotas and eastern Nebraska.

However, there is a large land formation when seen from a distance, rises above the plains and breaks up the monotonous landscape around you. If you travel interstate highway I-29 south from Fargo, North Dakota or west on U.S. highway 12 from Minneapolis, Minnesota these hills are strikingly noticeable as you approach the South Dakota state border.
Early French born scientist and explorer, Joseph Nicollet, was the first individual to extensively map the upper Midwest region between the Missouri and Mississippi rivers. On these maps he outlined the Coteau des Prairie, which is French for "Hills of the Prairie." The name has been Americanized to Prairie Coteau.

The Prairie Coteau region, which Nicollet explored and described, lies mostly in South Dakota directly opposite of the Black Hills (Fig. 1). It is approximately 5 million acres in size, and includes the eastern escarpment and the Big Sioux River basin, with the tip located just inside the North Dakota border and the southern end fanning-out into southwestern Minnesota and northwestern Iowa.

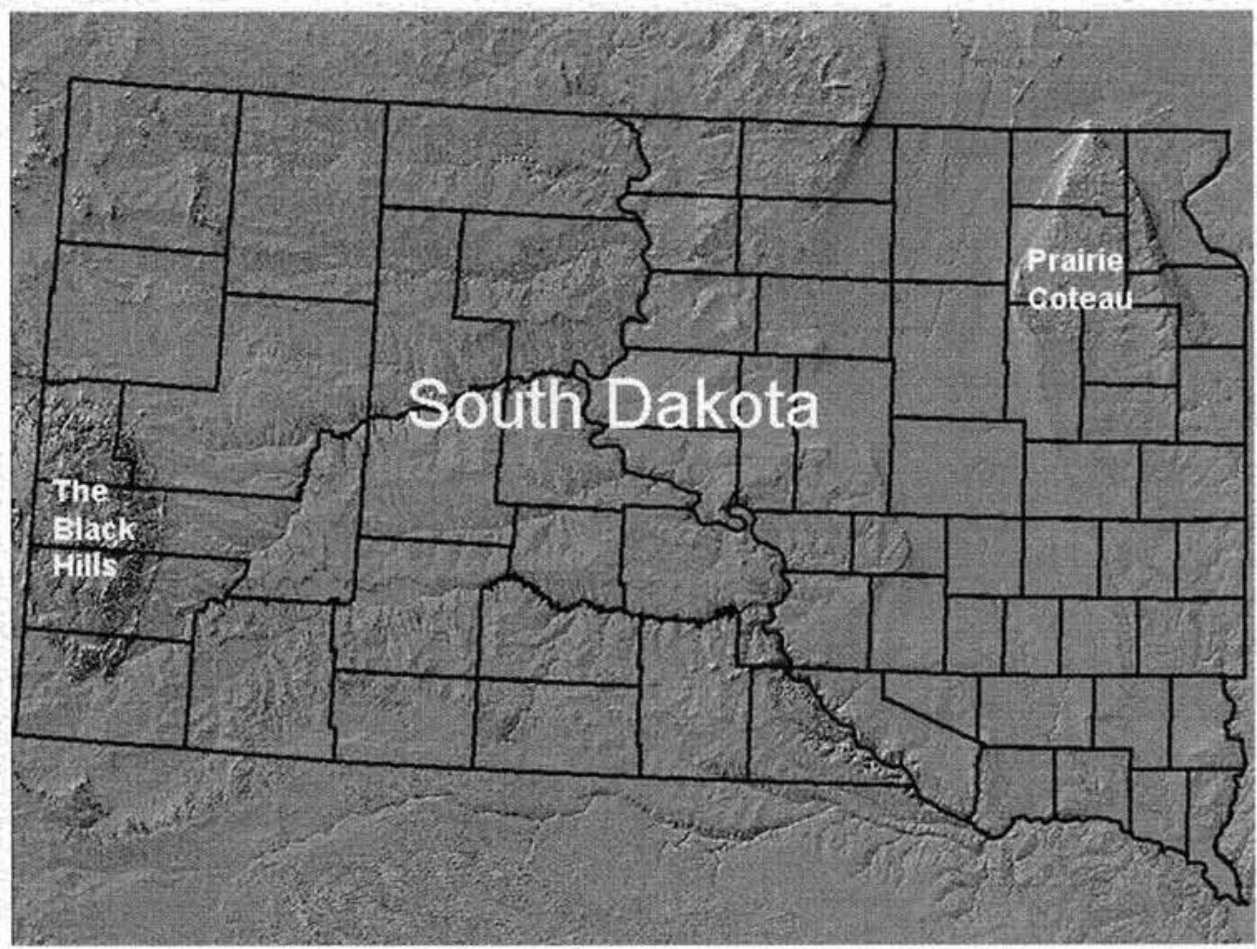

Figure 1. The Coteau Des Prairie or Prairie Coteau is located on the eastern side of South Dakota (Map created by SDSU Wildlife and Fisheries Science Department GIS Lab 2003). 
In 1838 and 1839, Nicollet led separate expeditions, financed by the United States Topographical Bureau of the War Department, into this region. These expeditions led to the 1843 and 1845 publication by the U.S. government of Nicollet's Map of the Hydrographical Basin of the Upper Mississippi River and a Report Intended to Illustrate a Map of the Hydrographical Basin of the Upper Mississippi River. These publications added significantly to the history and geography of North America. Nicollet was a scientist ahead of his time, using barometric measurements at different locations to determine elevation. He also developed a very friendly and respectful relationship with Indians of many tribes, who allowed him to move more freely in this relatively unexplored region.

\section{Geologic Markers}

The underlying bedrock of this region is composed primarily of Pierre shale in the northern portion of the Prairie Coteau and

- Sioux Quartzite at the southeastern edge of the Prairie Coteau. Exposed Pierre shale, with its coal-like appearance, can be seen on the eastern escarpment on South Dakota state highway 10 west of Sisseton, South Dakota. Sioux Quartzite is exposed in many places from the cutting action of water over time and displays beautiful rugged formations, one of which creates a waterfall from which the city of Sioux Falls, South Dakota derived its name.

Over lying the bedrock is a deposit of glacial till varying in thickness, composition, and topo-

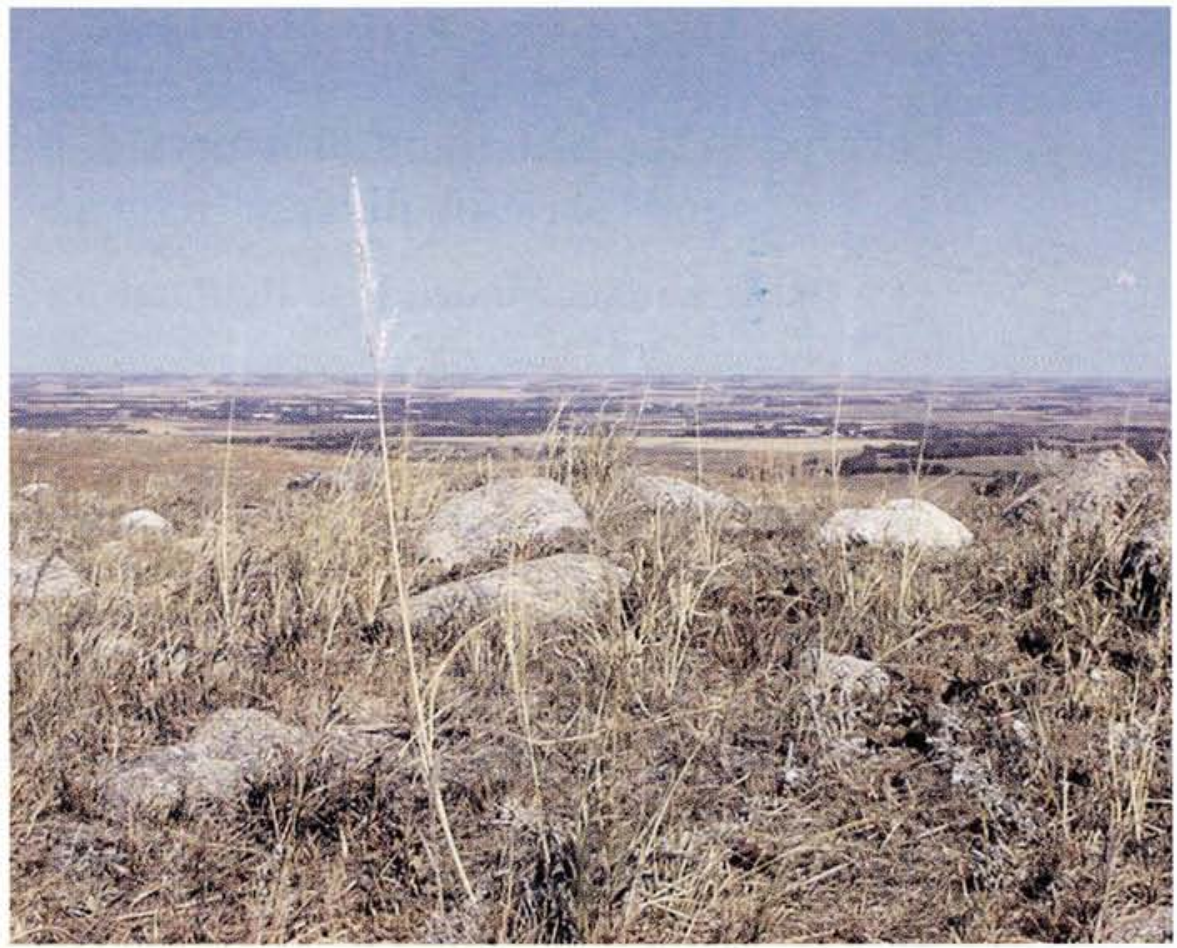

Figure 2. Photo taken in September, looking northeast into the Red River Valley some 600 feet below from a vantage point on the eastern edge of the Prairie Coteau just south of Sisseton, South Dakota. Note the boulder outcropping, which is a typical feature of the glacial moraines in this area. This tall, yellowish tiller in the foreground is prairie sandreed (Calamovilfa longifolia).

graphical relief from past glacial lobes that advanced and retreated on either side of the Prairie Coteau. This rocky glacial till has kept large areas, especially in the northern parts of the Coteau, from being plowed (Fig. 2).

Where geological erosion has smoothed the rugged areas most of the land has been farmed (approximately $65 \%$ ). Only where the terrain is steep, is abundant in surface rocks, or is poorly drained and low, does pasture remain. These pasture areas are dominated by a mixture of coolseason and warm-season native grass species with an abundance of native forbs and shrubs representative of the northern tallgrass prairie.
A floristic survey, conducted by the Nature Conservancy, of the Crystal Springs Prairie located near Clear Lake, South Dakota identified 232 species of grasses, forbs, shrubs, and trees, an impressive degree of species diversity typical of prairie remnant areas. In addition to the native warm-season grasses that commonly depict the tallgrass prairie, the Prairie Coteau has native cool-season grasses such as, porcupine grass (Stipa spartea), green needlegrass (Stipa viridula), and Canada wildrye (Elymus canadensis) due to its northern latitude. The Prairie Coteau also harbors a variety of habitats including, forested coulees, wetlands, fens, and lakes (Figures 3, 4 , and 5). 


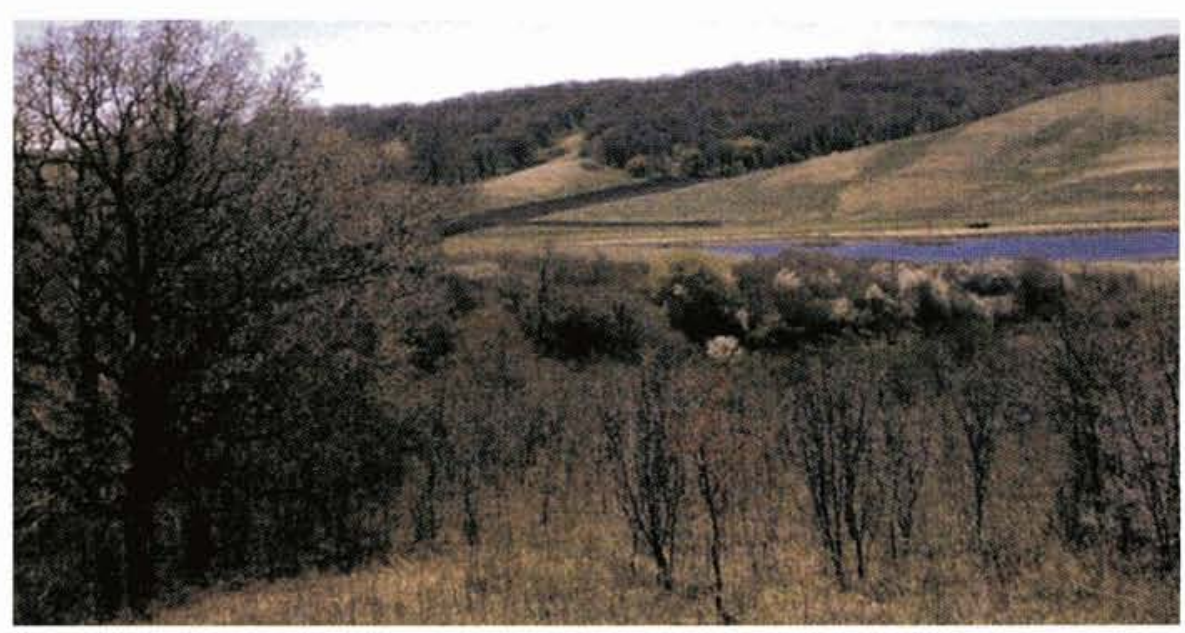

Figure 3. Oakwoodlands in springtime at The Nature Conservancy's Hole-in-the Mountain Preserve near Lake Benton, Minnesota.

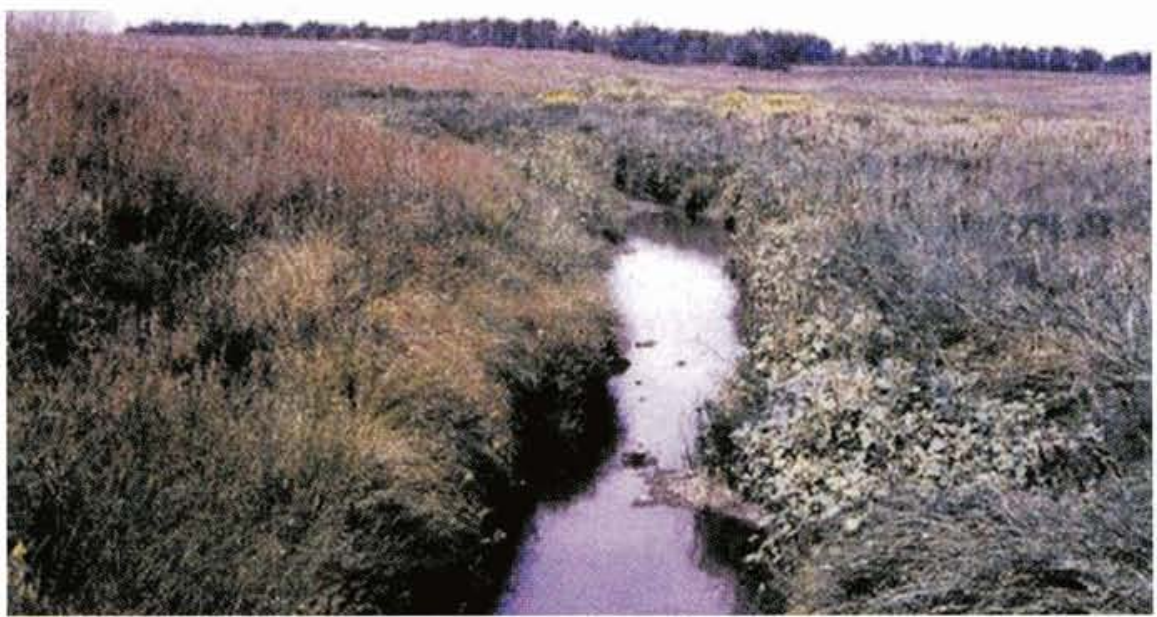

Figure 4. Monighan creek located in the Crystal Springs Prairie near Clear Lake, South Dakota.

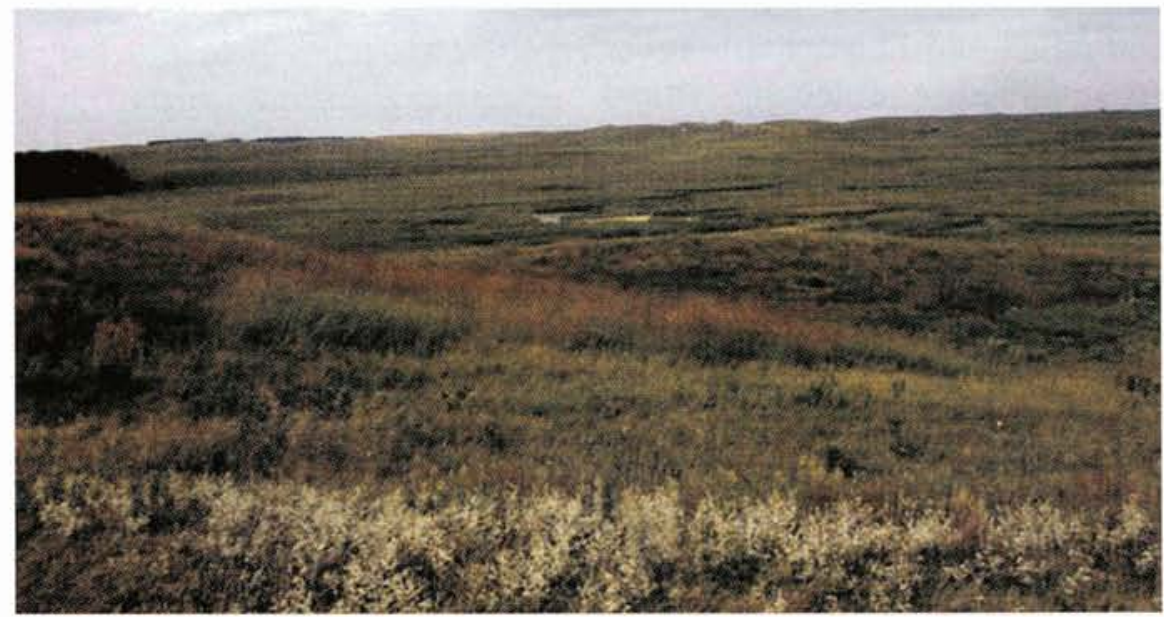

Figure 5. Jacobson Fen at Crystal Springs Prairie near Clear Lake, South Dakota.

\section{Working to Preserve this Prairie}

Cropping has highly fragmented this ecosystem which has changed many aspects of the ecosystem. For example, fragmentation has increased edge effects, reduced habitat size, and intensified competition for resources leading to species elimination and replacement. The tallgrass prairie remains as isolated, unplowed prairie remnants and pastureland. In Figure 6, the natural vegetation represented by green shading on the map represents one of the areas where large contiguous acres of the northern tallgrass prairie still remain.

It is estimated that $78 \%$ of the hayland, idle grassland, and pastureland of the region is located in the northern half of the Prairie Coteau. The southern half of the Prairie Coteau is highly fragmented by cropland and only accounts for $22 \%$ of the hayland, idle grassland, and pastureland. It is also estimated that $17.6 \%$ of the total land area surveyed in the Prairie Coteau exists as tallgrass prairie vegetation.

In some areas overstocking, lack of fire, herbicide use, and land use have led to invasion of exotic cool-season grasses and forbs, such as smooth bromegrass (Bromus inermis Leyss.), Kentucky bluegrasss (Poa pratensis L.), Canada thistle [Cirsium arvense (L.) Scop.], and leafy spurge (Euphorbia esula L.).

Livestock production is an important part of the local economy of the counties in the Prairie Coteau region. Pastureland in the Prairie Coteau region represents $4 \%$ of South Dakota's total pastureland but, the Prairie Coteau is 


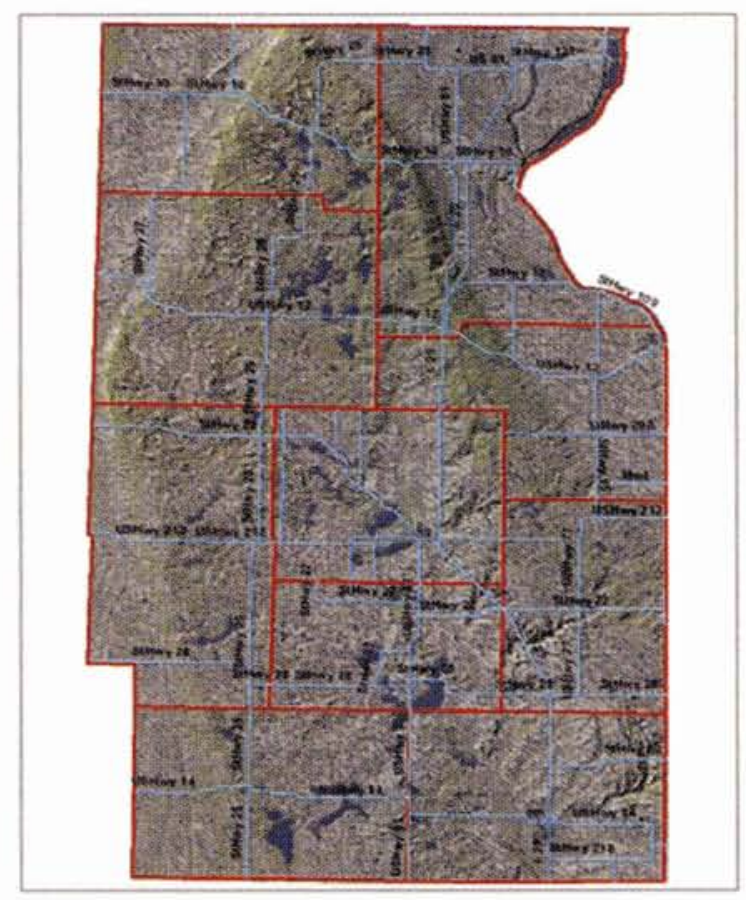

Figure 6. The Prairie Coteau of South Dakota located in the Northern Tallgrass Prairie Ecoregion. Green areas represent large patches of unfragmented vegetation, blue areas indicate water, and lighter shading indicates cropland (Map created by SDSU Wildlife and Fisheries Science Department GIS Lab 2003).

highly productive, as $15 \%$ of all beef cows, $49 \%$ of all milk cows, and $14 \%$ of all sheep for the state of South Dakota are produced in this region.

The Nature Conservancy has designated this region as worthy of protection because it contains large remnants of northern tallgrass prairie and its associated flora and fauna. Other agencies that have identified the Prairie Coteau as critical for conservation are the World Wildlife Fund and the United States Fish and Wildlife Service. South Dakota Game Fish and Parks (SDGFP) have protected important areas for public use such as, hunting, fishing, and recreation. The State Heritage Program, administered by SDGFP, has identified over 400 plants and animals on the Prairie Coteau worthy of monitoring, and the area has been an in-

Additionally, the Heritage Program has worked with The Nature Conservancy to identify key regions on the Prairie Coteau that have significant species diversity. In addition, local soil conservation districts and conservation organizations such as, Ducks Unlimited and Pheasants Forever are involved in protecting critical habitat.

Another noticeable feature of the Prairie Coteau is the abundance of lakes, rivers, streams, and wetlands. In figure 6 , the blue shaded areas represent water. As you would expect, fishing and recreational uses of these water bodies is very important to the economy of northeastern South Dakota. In addition, the abundance of water provides excellent waterfowl habitat for game and nongame species, and the region is a critical stop for migratory species.

The Prairie Coteau with its unique geography and resources, have provided many people the opportunity to make a living from crop and livestock production. The rich diversity of land, water, animal, and plant life has attracted people who want to enjoy and protect these resources. Interested agencies and private organizations do not have a monopoly on conservation. Many private landowners are equally interested in conservation, and take stewardship very seriously because it ultimately relates to long-term economic sustainability.

Working together through education and listening to the needs of landowners and the wants of conservation parties, we can successfully pass down to future generations a beautiful environment called the Prairie Coteau.
About the Authors: Alexander Smart is an Assistant Professor/Range Scientist at South Dakota State University in Brookings, S.D. Pete Bauman is a Land Steward with the Nature Conservancy for the Prairie Coteau region in Clear Lake, S.D. Barry Dunn is an Assistant Professor/Range Extension Specialist at South Dakota State University.

\section{Suggested Reading}

Bray, E.C., and M.C. Bray. 1993. Joseph N. Nicollet on the Plains and Prairies: The expeditions of 1838-39 with journals, letters, and notes on the Dakota Indians. Minnesota Historical Society Press. St. Paul, Minn.

Bray, M.C. 1994. Joseph Nicollet and his map. The American Philosophical Society. Philadelphia, Penn.

Hogan, E. P. 1995. The geography of South Dakota. Pine Hill Press, Inc. Freeman, S.D. 